WE investigated the serum concentration of vascular endothelial growth factor (VEGF) and its two soluble receptors, sVEGFR-1 and sVEGFR-2, in a group of 60 patients with systemic lupus erythematosus (SLE), and 20 healthy controls, using an enzyme-linked immunosorbent assay. We examined a possible association between serum levels of these proteins and certain clinical and laboratory parameters as well as SLE activity. VEGF, SVEGFR-1 and SVEGFR-2 were detectable in all patients with SLE and in all normal individuals. The VEGF level was higher in active SLE (mean, $300.8 \mathrm{pg} / \mathrm{ml}$ ) than in inactive SLE (mean, $165.9 \mathrm{pg} / \mathrm{ml})(p<0.05)$ or in the control group (mean, 124.7 pg/ml) $(p<0.04)$. The highest SVEGFR- 1 concentrations were also detected in active SLE patients (mean, $42.2 \mathrm{pg} / \mathrm{ml}$ ) and the lowest in inactive disease (mean, $32.0 \mathrm{pg} / \mathrm{ml})(p<0.01)$. In contrast, the levels of SVEGFR-2 were lower in SLE (mean, $12557.6 \mathrm{pg} / \mathrm{ml}$ ) than in the control group (mean, $15025.3 \mathrm{pg} / \mathrm{ml})(p<0.05)$. We found a positive correlation between SVEGFR-1 concentration and the SLE activity score $\rho=0.375(p<0.004)$ and a negative, but statistically insignificant correlation between SVEGFR-2 and SLE activity $(\rho=-0.190$, $p>0.05)$. Treatment with steroids and cytotoxic agents did not influence VEGF or its soluble receptors levels. In conclusion, in SLE patients the levels of VEGF and sVEGFR-1 are higher in patients with active SLE than in inactive disease or healthy persons. In contrast, the level of SVEGFR-2 is lower in active SLE than in inactive disease. The imbalance between VEGF and its soluble receptors may be important in SLE pathogenesis.

Key words: Angiogenesis, VEGF, Soluble VEGF receptors, FLK-1, fms-like tyrosine kinase 1, Systemic lupus erythematosus, Disease activity

\section{Vascular endothelial growth factor and its soluble receptors VEGFR-1 and VEGFR-2 in the serum of patients with systemic lupus erythematosus}

\author{
Ewa Robak', Anna Sysa-Jędrzejewska ${ }^{1}$ and \\ Tadeusz Robak ${ }^{2, C A}$
}

${ }^{1}$ Department of Dermatology and Venerology, Medical University of Lódź and ${ }^{2}$ Department of Hematology, Medical University of Lódź, 93-513 Lódź, ul. Pabianicka 62, and Copernicus Memorial Hospital Lódź, Poland

\author{
${ }^{\mathrm{CA}}$ Corresponding Author \\ Tel: +48426895191 \\ Fax: +48426895192 \\ E-mail: robaktad@csk.am.lodz.pl
}

\section{Introduction}

Vascular endothelial growth factor (VEGF) is a key regulator of vasculogenesis and angiogenesis., ${ }^{1,2}$ VEGF is produced by endothelial cells, macrophages, fibroblasts and smooth muscle cells. ${ }^{1}$ It is a chimeric glycoprotein with a molecular weight of $34-45 \mathrm{kDa}$, consisting of two subunits. ${ }^{3,4}$ Five isoforms of human VEGF have been described to date, each generated by alternative splicing of a single mRNA and resulting in proteins of varying amino acid length, (VEGF). ${ }^{121,145,165,189,206}$ This angiogenic cytokine binds to receptors on endothelial cells and acts as direct inducer of angiogenesis both in vivo and in vitro. ${ }^{5}$ The two best characterised VEGF receptors are termed VEGF receptor 1 (VEGFR-1) and VEGF receptor 2 (VEGFR-2). VEGFR-1 ( $\mathrm{fms}$-like tyrosine kinase 1) and VGFR-2 (kinase domain receptor/ FLK-1) are specific tyrosine kinase receptors that together with platelet-derived growth factor re- ceptors form the subtype III of tyrosine kinase receptors. ${ }^{2,6-8}$ The gene for VEGFR-1 is almost exclusively expressed on endothelial cells but is also found on monocytes. ${ }^{\text {" VEGFR-2 }}$ is not found on monocytes. Both receptors share common features such as seven immunglobulin-like extracellular domains, a single transmembrane region and a consensus tyrosine kinase sequence interrupted by a kinase insert domain, and they are highly glycosylated. ${ }^{10,11}$ However, although VEGFR-1 binds to VEGF with substantially higher affinity, most of the biological effects of VEGF seem to be mediated via VEGFR-2. ${ }^{12}$

Recently, a naturally occurring soluble form of VEGFR-1 (sVEGFR-1) has been identified, but naturally occurring secreted forms of sVEGFR-2 have not been reported to date. ${ }^{11,13-15}$ The physiological role of sVEGFR-1 and sVEGFR-2 is still undetermined. It has been shown that sVEGFR-1 retains its highaffinity binding to VEGF and it is likely to be a 
negative regulator of VEGF availability, or that it may prolong the different VEGF activities. ${ }^{13,16-18}$

Angiogenic cytokines and angiogenesis inhibitors play an important role in the pathogenesis of several diseases including connective tissue diseases. ${ }^{19-22}$ In our previous studies we have shown that in SLE patients the serum level of some angiogenic cytokines is higher than in healthy controls, but the level of endostatin, the endogenous angiogenesis inhibitor, is similar in SLE and in the control group. ${ }^{21,22}$ Moreover, selected pro-angiogenic cytokines correlated with SLE activity.

In the present study we measured the serum concentrations of VEGF and its soluble receptors VEGFR-1 and VEGFR-2 in patients with SLE using an enzyme-linked immunosorbent assay. The serum levels of these proteins were also correlated with disease activity and some clinical and laboratory parameters. To the best of our knowledge, the serum levels of sVEGFR-1 and sVEGFR-2 in patients with SLE have not been investigated to date.

\section{Patients and methods}

The study group consisted of 60 patients with SLE (55 females and five males) and 20 sex-matched and agematched healthy volunteers. The median age of the SLE patients was 41 years (range, $18-75$ years). The diagnosis of SLE was based on the revised criteria of the American Rheumatism Association. ${ }^{23}$ The mean duration of the disease was 71 months (range, 3 months -24 years). Twenty-four patients were never treated with steroids or any other immunosuppressive agents. Fourteen patients were treated with prednisone at a dose of $5-20 \mathrm{mg}$ /day during the study and five patients with prednisone and azatioprine or cyclophosphamide. Patients' histories were recorded and physical examination was performed on the day of blood collection. Patients with both active and inactive disease were included in the study. In all patients the activity of the disease was determined according to the systemic lupus activity measure (SLAM) scale. ${ }^{24}$ Each patient was examined on two separate occasions 2-4 weeks apart. The SLAM system includes 24 clinical manifestations and eight laboratory parameters. The maximum score in this system is 84 points. In our group of patients, the number of points ranged from 9 to 27 . In the present study we considered a score of $0-15$ points as inactive disease and a score over 15 points as active disease. By this definition active disease was found in 32 patients and 28 patients had inactive disease.

The clinical and laboratory features of SLE patients are presented in Table 1. A control group of 20 healthy volunteers (17 women and three men) aged from 35 to 58 years (median, 45 years) was also
Table 1. Clinical and laboratory characteristics of SLE patients

\begin{tabular}{|c|c|c|}
\hline Symptoms & $\begin{array}{l}\text { Number of } \\
\text { patients }\end{array}$ & $\%$ \\
\hline Total & 60 & 100 \\
\hline $\begin{array}{l}\text { Age (years) [mean } \\
\text { (range)] }\end{array}$ & $41(18-79)$ & \\
\hline Sex (male/female) & $5 / 55$ & $8.3 / 91.7$ \\
\hline Active/inactive & $32 / 28$ & $53.3 / 46.7$ \\
\hline Fever & 15 & 25.0 \\
\hline Arthritis & 54 & 90.0 \\
\hline Skin symptoms & 30 & 50.0 \\
\hline $\begin{array}{l}\text { Reticuloendothelial system } \\
\text { involvment }\end{array}$ & 32 & 53.3 \\
\hline $\begin{array}{l}\text { Renal disorder (kreatinine } \\
\quad>1.3 \mathrm{mg} / \mathrm{dl} \text { ) }\end{array}$ & 5 & 8.3 \\
\hline Neurologic symptoms & 35 & 58.3 \\
\hline Antinuclear antibodies & 49 & 81.6 \\
\hline $\begin{array}{l}\text { Immunoglobulins deposit at } \\
\text { the dermal-epidermal junction }\end{array}$ & 33 & 55 \\
\hline $\begin{array}{l}\text { Anaemia (haemoglobin } \\
<12 \mathrm{~g} / \mathrm{dl} \text { ) }\end{array}$ & 30 & 50.0 \\
\hline $\begin{array}{l}\text { Leukopaenia (white blood cells } \\
\left.\quad<3.5 \times 10^{9} / \mathrm{l}\right)\end{array}$ & 20 & 33.3 \\
\hline $\begin{array}{l}\text { Thrombocytopaenia (platelets } \\
\quad<150 \times 10^{9} / \text { l) }\end{array}$ & 14 & 23.3 \\
\hline $\begin{array}{l}\text { C-reactive protein } \\
(>4.7 \mathrm{mg} / \mathrm{L})\end{array}$ & 15 & 25.0 \\
\hline Raised ESR ( $>25 \mathrm{~mm} / \mathrm{h})$ & 24 & 41.6 \\
\hline $\begin{array}{l}\text { Treatment with steroids } \\
\text { during the study }\end{array}$ & 14 & 23.3 \\
\hline $\begin{array}{l}\text { Treatment with steroids and } \\
\text { cytoxic agents during the study }\end{array}$ & 5 & 8.3 \\
\hline
\end{tabular}

studied. Each person underwent a thorough physical evaluation by one of the authors (E.R.). The patients with SLE and controls showed no clinical signs of infections or neoplastic disease and were not given antibiotics or any other antibacterial or antiviral medication for at least 4 weeks prior to blood donation. This project was performed in accordance with the Helsinki Declaration and was approved by the local Ethics Committee. Informed consent was obtained from all the patients.

\section{Laboratory tests}

In the study group the following laboratory parameters were analysed: complete blood cell count, erythrocyte sedimentation rate (ESR), urinalysis, blood urea nitrogen and creatinine levels, fibrinogen, partial thromboblastin time, alanine aminotransferase (ALT), asparate aminotransferase (AST), bilirubin, immunoglobulins (IgG, IgM and IgA) and complement $\left(\mathrm{C}_{3}, \mathrm{C}_{4}\right)$ levels and antinuclear antibodies. Immunoglobulin deposits at the dermal-epidermal junction (lupus band test) were also determined.

\section{Serum sampling and detection of VEGF and its soluble receptors}

Venous blood $(5 \mathrm{ml})$ was collected in pyrogen-free tubes, allowed to dot at $4^{\circ} \mathrm{C}$ for $1 \mathrm{~h}$ and centrifuged at $2000 \mathrm{~g}$ for $10 \mathrm{~min}$. The sera obtained were allocated 
into separate vials and stored at $-25^{\circ} \mathrm{C}$ until assayed for VEGF and its soluble receptors. The serum was randomly coded and the testing was carried out without knowledge of the clinical status of the subject or of any related laboratory data. The cytokines serum concentrations were assayed by specific, commercially available, enzyme-linked immunosorbent assay kits (Qantikine; R\&D Systems Inc., Minneapolis, Minnesota, USA) using horseradish peroxidase detection in accordance with the manufacturer's instructions. The absorption was red at 492 $\mathrm{nm}$. In each assay the appropriate recombinant human cytokine or receptor was used to generate the standard curve. Standards as well as samples were assayed as duplicates and the inter-assay variations were shown to be with the range given by the manufacturer. The procedure has previously been described in detail. ${ }^{22,25}$ The sensitivity of the assay for VEGF was $<5.0 \mathrm{pg} / \mathrm{ml}$ with intra-assay and inter-assay coefficients of variation of $5.1 \%(n=20)$ and $6.2 \%(n=40)$ at $0.9 \mathrm{ng} / \mathrm{ml}$ and $1.0 \mathrm{ng} / \mathrm{ml}$. The mean minimum detectable dose of VEGFR-1 was 5.01 $\mathrm{pg} / \mathrm{ml}$ and ranged from $1.63-14.4 \mathrm{pg} / \mathrm{ml}$, with intraassay and inter-assay coefficients of variation of $3.5 \%$ $(n=20)$ and $8.1 \%(n=40)$ at $1.5 \mathrm{ng} / \mathrm{ml}$. Serum for the sVEGFR-2 concentration measurement was diluted five-fold. The mean value of minimum detectable dose was $4.6 \mathrm{pg} / \mathrm{ml}$ (range, $1.0-11.4 \mathrm{pg} / \mathrm{ml}$ ) with intra-assay and inter-assay coefficients of variation of $2.9 \%(n=20)$ and $5.7 \%(n=40)$ at $2.9 \mathrm{ng} / \mathrm{ml}$. The concentrations of VEGF and soluble VEGF receptors in the samples were determined by interpolation from the standard curve.

\section{Statistical analysis}

For the statistical analysis of the data the range of measured variable is given (minimum-maximum). The mean arithmetic value, median and standard deviation were also calculated. The medians were compared using the Mann-Whitney test and the Kruskal-Wallis test. The correlation between features was evaluated using the Spearman rank coefficient $p$. Comparisons and correlations were considered significant when $p<0.05$.

\section{Results}

In the group of 60 SLE patients, 32 were with active and 28 with inactive disease according to the Liang et al. scoring system. ${ }^{24}$ The serum concentrations of VEGF and its soluble receptors sVEGFR-1 and sVEGFR-2 were detectable in all SLE patients and in healthy volunteers. The results are presented in Table 2. The highest VEGF concentration was found in patients with active SLE (mean, $234.2 \mathrm{pg} / \mathrm{ml}$ ) and the lowest in the healthy control group $(124.7 \mathrm{pg} / \mathrm{ml})$ $(p<0.04)$. No difference in VEGF serum concentrations in inactive SLE compared with normal individuals was observed. The serum level of VEGF was significantly higher in patients with active disease as compared with patients with inactive SLE (Table 2).

The highest sVEGFR-1 concentrations were also detected in active SLE patients (mean, $42.4 \mathrm{pg} / \mathrm{ml}$ ) and the lowest in inactive SLE patients (mean, 32.0 $\mathrm{pg} / \mathrm{ml})(p<0.01)$. The level of this soluble receptor in inactive SLE and in healthy individuals were not statistically different. In contrast, the levels of sVEGFR-2 in active and inactive SLE patients were similar (Table 2). However, the concentrations of this receptor in SLE patients were lower (mean, $12.5 \mathrm{ng}$ / $\mathrm{ml}$ ) than in the control group (mean, $15.0 \mathrm{ng} / \mathrm{ml}$ ) $(p<0.05)$. We found a positive correlation between sVEGFR-1 concentration and the SLE activity score $(\rho=0.375, p<0.004)$ and a negative but statistically not significant correlation between sVEGFR-2 and SLE activity (Fig. 1).

We analysed the correlation between serum levels of VEGF and sVEGFR-1 $(\rho=0.166)$, VEGF and sVEGR-2 $(\rho=-0.053)$ as well as sVEGFR-1 and sVEGFR-2 $(\rho=0.043)$. However, the differences were not statistically significant $(p<0.05)$ (data not shown).

Table 2. Serum levels of VEGF and its soluble receptors (sVEGFR-1 and sVEGFR-2) in patients with SLE and control group

\begin{tabular}{|c|c|c|c|c|c|}
\hline Cytokine/receptors & $\begin{array}{c}\text { All SLE } \\
(n=60)(a)\end{array}$ & $\begin{array}{l}\text { Active SLE } \\
(n=32)(\mathrm{b})\end{array}$ & $\begin{array}{l}\text { Inactive SLE } \\
(n=28)(c)\end{array}$ & $\begin{array}{l}\text { Control group } \\
(n=20)(\mathrm{d})\end{array}$ & $\begin{array}{c}\text { Statistically significant } \\
\text { comparison }\end{array}$ \\
\hline \multicolumn{6}{|l|}{ VEGF (pg/ml) } \\
\hline$x \pm S D$ & $234.2 \pm 209.9$ & $300.8 \pm 250.9$ & $165.3 \pm 153.4$ & $124.7 \pm 59.7$ & (b) - (c) $-(\mathrm{d}), p=0.05$ \\
\hline Median & 150.4 & 202.4 & 116.1 & 123.5 & (b) - (c), $p<0.05$ \\
\hline Range & $6.4-920.4$ & $8.5-920.4$ & $6.4-602.4$ & $21.1-218.5$ & (b) - (d), $p<0.04$ \\
\hline \multicolumn{6}{|l|}{ sVEGFR-1 (pg/ml) } \\
\hline$x \pm S D$ & $37.5 \pm 14.5$ & $42.4 \pm 16.1$ & $32.0 \pm 10.1$ & $38.3 \pm 12.5$ & (b) - (c) - (d), $p<0.03$ \\
\hline Median & 36.3 & 39.5 & 31.2 & 38.25 & (b) - (c), $p<0.01$ \\
\hline Range & $9.9-88.2$ & $9.9-88.2$ & $13.8-49.7$ & $18.8-61.2$ & \\
\hline \multicolumn{6}{|l|}{ sVEGFR-2 (ng/ml) } \\
\hline$x \pm \mathrm{SD}$ & $12.5 \pm 3.6$ & $12.0 \pm 3.6$ & $13.2 \pm 3.6$ & $15.0 \pm 5.0$ & (a) - (d), $p<0.05$ \\
\hline Median & $12.0^{-}$ & $11.7^{-}$ & $12.7^{-}$ & $14.2^{-}$ & (b) - (d), $p<0.04$ \\
\hline Range & $5.0-23.2$ & $5.0-19.8$ & $7.9-23.2$ & $8.7-26$ & \\
\hline
\end{tabular}

$x \pm \mathrm{SD}$, Mean \pm standard deviation. 
We also investigated the correlation between the level of VEGF and its soluble receptors with selected clinical and laboratory parameters of the patients with SLE. In the group of 60 patients, 14 were treated with steroids and five with cytotoxic agents. However, the levels of VEGF, sVEGFR-1 and sVEGFR-2 were similar in both groups $(p>0.05)$ (data not shown). In contrast, the serum concentration of VEGF was higher in the patients with immunoglobulin deposit at the dermal-epidermal junction (mean, $288.6 \mathrm{pg} / \mathrm{ml}$ ) than in the patients without this symptom (mean, $162.2 \mathrm{pg} / \mathrm{ml})(p<0.02)$. The level of sVEGFR-2 was also higher in SLE patients with skin immunoglobulin deposits (mean, $13.2 \mathrm{ng} / \mathrm{ml}$ ) than in the patients without these deposits (mean, $11.7 \mathrm{ng} /$ ml) $(p<0.04)$. In contrast, sVEGFR-1 was similar in both groups (mean, $38.4 \mathrm{pg} / \mathrm{ml}$ and $36.2 \mathrm{pg} / \mathrm{ml}$, respectively; $p>0.05)$. The mean concentration of sVEGFR-1 was higher in SLE patients with anaemia (haemoglobin $<12 \mathrm{~g} / \mathrm{dl}$ ) at $43.3 \mathrm{pg} / \mathrm{ml}$ than in the patients with haemoglobin concentration $>12.0 \mathrm{~g} / \mathrm{dl}$ (31.9 $\mathrm{pg} / \mathrm{ml})(p<0.001)$. In contrast, the levels of VEGF and sVEGFR-2 were similar in both groups $(p>0.05)$. The VEGF and VEGFR-1 serum levels were higher in the SLE patients with a high C-reactive protein level (CRP) ( $>4.7 \mathrm{mg} / \mathrm{l})$ (mean values, 361.0 $\mathrm{pg} / \mathrm{ml}$ and $44.1 \mathrm{pg} / \mathrm{ml}$, respectively) than among patients with a low CRP $(<4.7 \mathrm{mg} / \mathrm{l})(192.2 \mathrm{pg} / \mathrm{ml}$ and $35.2 \mathrm{pg} / \mathrm{ml}$, respectively) ( $p<0.02$ and $p<0.01$, respectively). The level of sVEGFR-2 was similar in both groups $(p>0.05)$. We also analysed the relationship between VEGF, sVEGFR-1 and sVEGFR-2 serum levels in the patients with and without skin symptoms, neurological symptoms, renal disorders (kreatinine $>1.3 \mathrm{mg} / \mathrm{dl}$ ), fever, arthritis, antinuclear antibodies, raised ESR ( $>25 \mathrm{~mm} / \mathrm{h}$ ) and thrombocytopaenia (platelets $<150 \times 10^{9} / 1$ ). We found no statistically significant differences in the levels of these cytokines or receptors in particular groups of patients.

\section{Discussion}

The results of numerous studies indicate that VEGF is one of the main positive regulators of angiogenesis. We have shown previously that in patients with active SLE the serum concentration of this cytokine is higher than in healthy controls or patients with inactive disease. ${ }^{21}$ We have also observed a positive but not statistically significant correlation between the VEGF concentration and the concentration of angiogenesisnegative regulator (i.e. endostatin). ${ }^{22}$ In these studies we have been the first to evaluate serum concentrations of VEGF soluble receptors (sVEGFR-1 and sVEGFR-2) in SLE patients and the relationship between these factors as well as their associations with SLE activity and some SLE laboratory and clinical parameters. The role of these receptors in the pathogenesis of autoimmune diseases has not been known until now.

It has been shown that mRNA for a soluble form of VEGFR-1 was generated by the alternative splicing in human umbilical vein endothelial cells and that sVEGFR-1, as a competitive inhibitor, was able to bind all isoforms of VEGF and to inhibit VEGFinduced endothelial cell proliferation. ${ }^{13}$ It has been suggested that sVEGFR-1 is likely to be a negative regulator of VEGF availability by sequestering the ligand and by forming inactive heterodimers with membrane-bound VEGF receptors. In this way sVEGFR-1 acts as a specific endogenous antagonist of its membrane-bound counterparts. VEGFR-2 is also able to bind VEGF but that receptor ligand complex formation, in contrast to sVEGFR-1, is heparin dependent. ${ }^{16}$ Based on these findings, the soluble VEGF receptors may be involved in the pathophysiology of SLE and their interaction with VEGF as a potential VEGF inhibitor and that they may influence the clinical course of SLE and the disease activity.

In our study we have revealed that the sVEGFR-1 concentration is the highest in active SLE, whereas levels of this receptor in inactive disease and in healthy individuals are comparable. To our knowledge soluble receptors of VEGF have not been previously determined in autoimmune diseases. However, a higher sVEGFR level has been detected in serum or plasma of patients with some haematopoietic system neoplasms or renal cancer ${ }^{26-28}$ and also in healthy people. ${ }^{29}$ In up-to-date studies endothelial cells and monocytes have been found to be the primary source of sVEGFR-1; however, the regulation of switching the transcription from the transmembrane to the soluble form is still not fully elucidated. $^{30}$ Moreover, it has been shown that hypoxia and also pro-angiogenic cytokines, VEGF and basic fibroblast growth factor cause up-regulation of sVEGFR-1 expression in endothelial cells. ${ }^{30,31}$ The serum level of these angiogenic cytokines in SLE patients appears to be higher, ${ }^{21}$ which might indicate that they are at least partially responsible for the increase in sVEGFR-1 serum concentration. Moreover, the sVEGFR-1 and VEGF complex can prolong the VEGF half-life through prevention of this cytokine proteolysis, lengthening in this way its activity. ${ }^{17}$ In our study, however, we have not observed a positive correlation between VEGF and sVEGFR-1 concentrations.

Contrary to sVEGFR-1, the sVEGFR-2 serum concentration in SLE patients was considerably lower than in healthy controls and did not correlate with the disease activity. These differences are difficult to explain. It is, however, known that monocytes/ macrophages express a significant level of VEGFR-1 

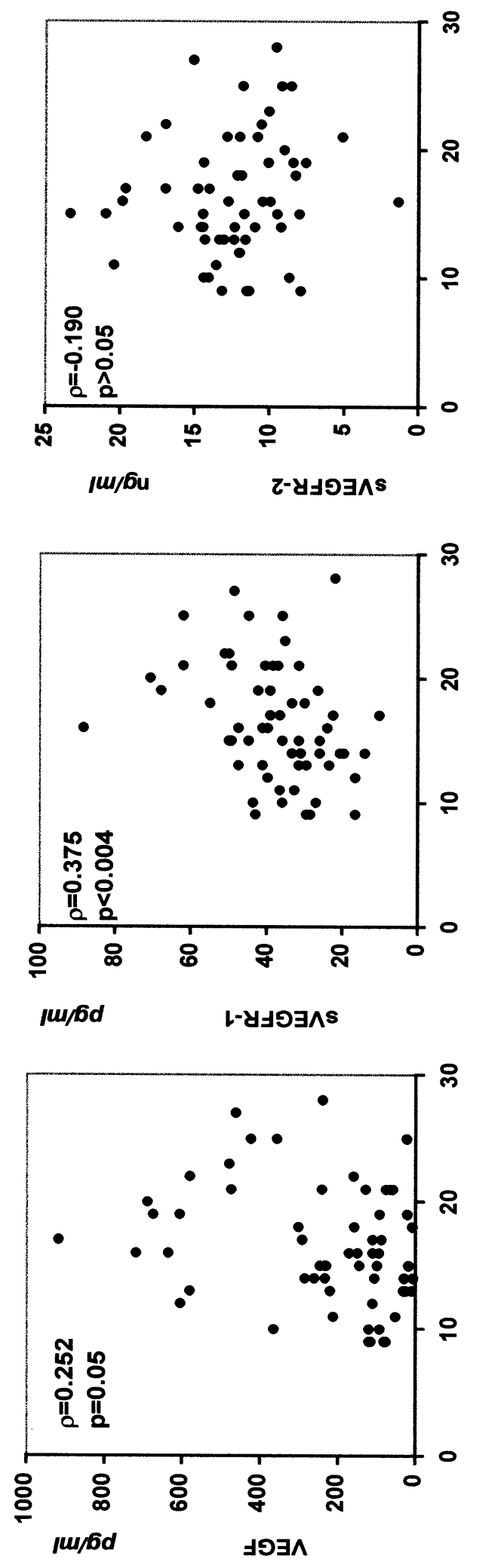

mRNA but very little, if any, VEGFR-2 mRNA. ${ }^{32}$ The biological activity of sVEGFR-2 is not completely understood. It has been shown to inhibit corneal neovascularisation induced by conditional media from a rat mammary carcinoma cell line. ${ }^{33}$ Furthermore, sVEGFR-2 can increase the number of capillaries displaying synchronous apoptosis in papillary membrane explant assay. ${ }^{34}$ Yet, the role of this receptor in SLE and other autoimmune diseases pathogenesis in vivo requires further investigations.

Differences in biological activity of both receptors should be emphasised. VEGFR-1 has a more than 10fold higher affinity to VEGF-A, even in a soluble form, but has about a 10-fold lower tyrosine kinase activity than VEGFR-2. ${ }^{35}$ In addition to sequestering the ligand, sVEGFR-1 can form heterodimers with transmembrane VEGFR-2, prevent its autophosphorylation and thus abolish signalling in a dominantnegative fashion. ${ }^{13}$ In this context the lack of balance between sVEGFR-1 and sVEGR-2 in serum of SLE patients is likely to have a pathogenetic impact and needs further studies.

In conclusion, in SLE patients the levels of VEGF and sVEGFR-1 are higher in patients with active SLE than in inactive disease or healthy persons. In contrast, sVEGFR-2 is lower in active SLE than in inactive disease. The imbalance between VEGF and its soluble receptors may be important in SLE pathogenesis.

ACKNOWLEDGEMENTS. This work has been supported by grant no 502-11783(26) awarded by the Medical University of Lódź Poland. The authors thank Ms Jolanta Fryczak for her invaluable technical assistance and Ms Elzbieta Dziankowska-Stachowiak for performing the statistical analysis of the data.

\section{References}

1. Plate KH, Warnke PC. Vascular endothelial growth factor. J Neurooncol 1997; 35: 365-372.

2. Jośko J, Gwóźdź B, Jędrzejewska-Szypulka H, Hendryk S. Vascular endothelial growth factor (VEGF) and its effect on angiogenesis. Med Sci Monit 2000; 6: 1047-1052.

3. Yancopoulos GD, Davis S, Gale NW, Rudge JS, Wiegand SJ, Holash J. Vascular specific growth factors and blood vessel formation. Nature 2000; 407: 242-248.

4. Houck KA, Ferrara N, Winer J, Cachianes G, Li B, Leung DW. The vascular endothelial growth factor family: identification of a fourth molecular species and characterization of alternative splicing of RNA. Mol Endocrinol 1991; 5: 1806-1814.

5. Risau W. Mechanisms of angiogenesis. Nature 1997; 386: 671-674.

6. Shibuya M, Yamaguchi S, Yamane A, Ikeda T, Tojo A, Matsushime H, Sato M. Nucleotide sequence and expression of a novel human receptor type tyrosine kinase gene (flt) closely related to the fms family. Oncogene 1990; 5: 519-524

7. Terman BI, Dougher-Vermazen M, Carrion ME, Dimitorv D, Armellino DC, Gospodarowicz D, Bohlen P. Identification of the KDR tyrosine kinase as a receptor for vascular endothelial cell growth factor. Biochem Biophys Res Commun 1992; 187: 1579-1586.

8. deVries C, Escobedo JA, Ueno H, Houck K, Ferrara N, Williams LT. The fms like tyrosine kinase, a receptor for vascular endothelial growth factor. Science 1992; 255: 989-991.

9. Clauss M, Weich H, Breier G, Knies U, Rockl W, Waltenberger J, Risau W. The vascular endothelial growth factor receptor Flt-1 mediates biological activities. J Biol Chem 1996; 271: 17629-17634.

10. Kondo K, Hiratsuka S, Subbalakshmi E, Matsushime H, Shibuya M. Genomic organziation of the flt-I gene encoding for vascular endothelial growth factor (VEGF) receptor-1 suggests an intimate evolutionary 
relationship between the 7-Ig and 5-Ig tyrosine kinase receptors. Gene 1997; 208: 297-305.

11. Hornig C, Behn T, Bartsch W, Yayon A, Weich HA. Detection and quantification of complex and free soluble human vascular endothelial growth factor receptor-1 (sVEGFR-1) by elisa. J Immunol Methods 1999; 226: $169-177$

12. Holash J, Davis S, Papadopoulos N, et al. VEGF-Trap aVEGF blocker with potent antitumor effects. Proc Natl Acad Sci USA 2002; 99: $11393-$ 11398.

13. Kendall RL, Wang G, Thomas KA. Identification of a natural soluble form of the vascular endothelial growth factor receptor, FLT-1 and its heterodimerization with KDR. Biochem Biophys Res Commun 1996; 226: $324-328$

14. Yamaguchi S, Iwata K, Shibuya M. Soluble Flt-1 (soluble VEGFR-1),a potent natural antiangiogenic molecule in mammals, is phylogenetically conserved in avians. Biochem Biophys Res Commun 2002; 291: $554-$ 559.

15. Hornig C, Barleon B, Ahmad S, Vuorela P, Ahmed A, Weich HA. Release and complex formation of soluble VEGFR-1 from endothelial cells and biological fluids. Lab Invest 2000; 80: 443-454.

16. Roeckl W, Hecht D, Sztajer H, Waltenberger J, Yayon A, Weich HA Differential binding characteristics and cellular inhibition by soluble VEGF receptors 1 and 2. Exp Cell Res 1998; 241: $161-170$

17. Hornig C, Weight HA. Soluble VEGF receptors. Angiogenesis 1999; 3: $33-38$.

18. Hasan J, Jayson GC. VEGF antagonists. Expert Opin Biol Ther 2001; 1 $703-718$.

19. Kadono T, Kikuchi K, Kubo M, Fuijmoto M, Tamaki K. Serum concentrations of basic fibroblast growth factor in collagen diseases. $J$ Am Acad Dermatol 1996; 35: 392-397.

20. Harada M, Mitsuyama K, Yoshida H, et al. Vascular endothelial growth factor in patients with rheumatoid arthritis. Scand J Rheumatol 1998; 27 377.

21. Robak E, Woźniacka A, Sysa-Jędrzejewska A, Stępien H, Robak T. Serum levels of angiogenic cytokines in systemic lupus erythematosus and their correlation with disease activity. Eur Cytokine Network 2001; 12: $445-$ 452.

22. Robak E, Woźniacka A, Sysa-Jędrzejewska A, Stępien H, Robak T. Circulating angiogenesis inhibitor endostatin and positive endothelial growth regulators in patients with systemic lupus erythematosus. Lupus 2002; 11: $348-355$

23. Tan EM, Cohen AS, Fries JF, et al. The 1982 revised criteria for the classification of systemic lupus erythematosus. Artchritis Rheum 1982 25: $1271-1277$.
24. Liang MH, Socher SA, Larson MG, Schur PH. Reliability and validity of six systems for the clinical assessment of disease activity in systemic lupus erythematosus. Arthritis Rheum 1989; 32: 1107-1118.

25. Robak T, Wierzbowska A, Błasińska-Morawiec, Korycka A, Błoński JZ. Serum levels of IL-6 type cytokines and soluble IL-6 receptors in active B-cell chronic lymphocytic leukemia and in cladribine induced remission. Mediat Inflamm 1999; 8: 277-286.

26. Belgore FM, Lip GY, Bareford D, Wadley M, Stonelake P, Blann AD Plasma levels of vascular endothelial growth factor (VEGF) and its receptor Flt-1, in hematological cancers: a comparison with breast cancer. Am J Hematol 2001; 66: 59-61.

27. Wierzbowska A, Robak T, Wrzesień-Kuś A, Krawczyńśka A, LechMarańda E, Urbańska-Ryś H. Circulating VEGF and its soluble receptors sVEGFR-1 and sVEGFR-2 in patients with acute leukemia. Eur Cytokine Network 2003; 14: 149-153.

28. Harris AL, Reusch P, Barleon B, Hang C, Dobbs N, Marme D. Soluble Tie 2 and Flt- 1 extra cellular domains in serum of patients with renal cancer and response to antiangiogenic therapy. Clin Cancer Res 2001; 7: $1992-$ 1997.

29. Barleon B, Reusch P, Totzke F, Herzog C, Keck C, Martiny-Baron G, Marme D. Soluble VEGFR-1 secreted by endothelial cells and monocytes is present in human serum and plasma from healthy donors. Angiogenesis 2001; 4: 143-154.

30. Toi M, Bando H, Ogawa T, Muta M, Hornig C, Weich HA. Significance of vascular endothelial growth factor (VEGF)/ soluble VEGF receptor-1 relationship in breast cancer. Int J Cancer 2002; 98: 14-18.

31. Barleon B, Siemeister G, Martiny-Baron G, Weindel K, Herzog C, Marme $D$. Vascular endothelial growth factor up regulates its receptor fms-like tyrosine kinase 1 (FLT-1) and a soluble variant of FLT-1 in human vascular endothelial cells. Cancer Res 1997; 57: 5421-5425.

32. Shibuya M. Structure and dual function of vascular endothelial growth factor receptor-1 (Flt-1). Int J Biochem Cell Biol 2001; 33: 409-420.

33. Lin P, Sankar S, Shan S, Dewhirst MW, Polverini PJ, Quinn TQ, Peters KG. Inhibition of tumour growth by targeting tumor endothelium using a soluble endothelial growth factor receptor. Cell Growth Differ 1998; 9: 49-58.

34. Meeson AP, Argilla M, Ko K, Witte L, Lang RA. VEGF-deprivationinduced apoptosis is a component of programmed capillary regression. Development 1999; 126: 1407-1415.

35. Ferrara N, Davis-Smyth T. The biology of vascular endothelial growth factor. Endocr Rev 1997; 18: 4-25.

\section{Received 14 July 2003}

Accepted 14 August 2003 


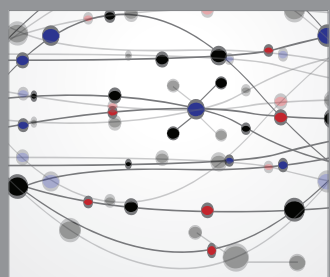

The Scientific World Journal
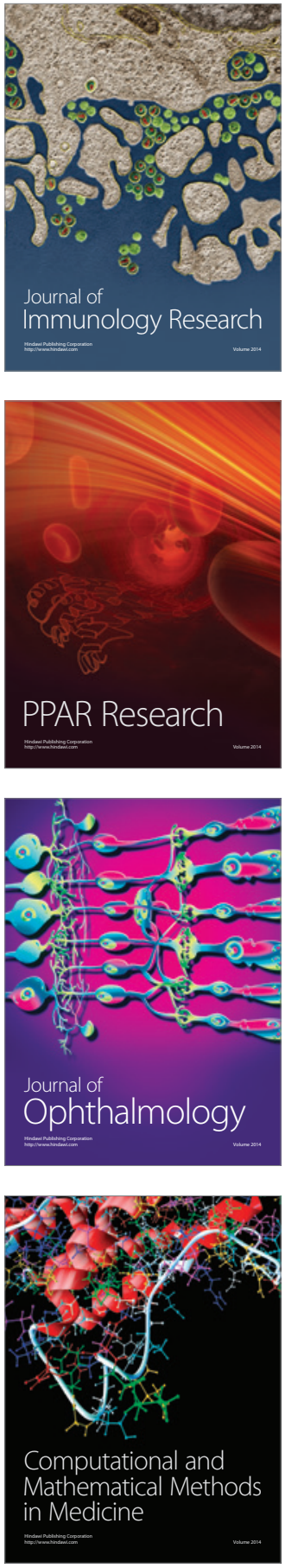

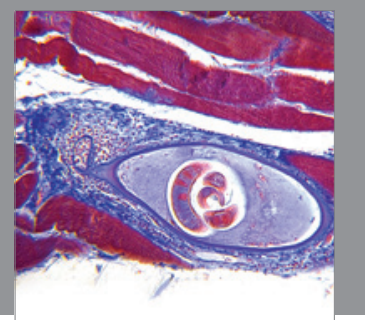

Gastroenterology

Research and Practice
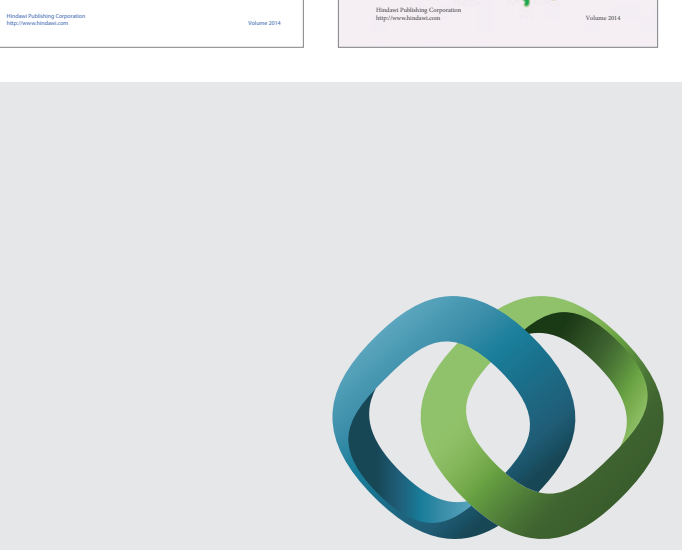

\section{Hindawi}

Submit your manuscripts at

http://www.hindawi.com
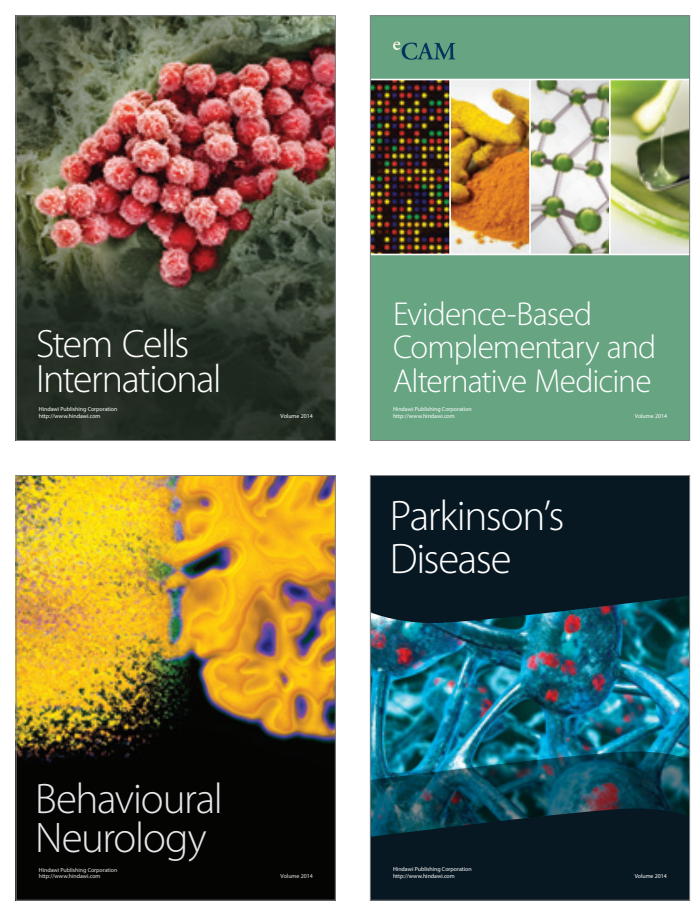

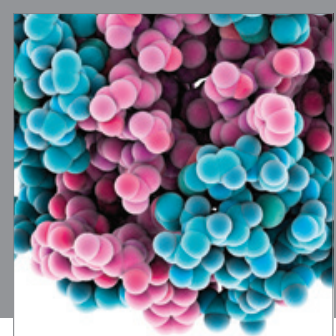

Journal of
Diabetes Research

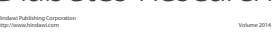

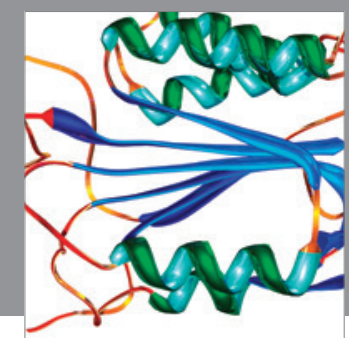

Disease Markers
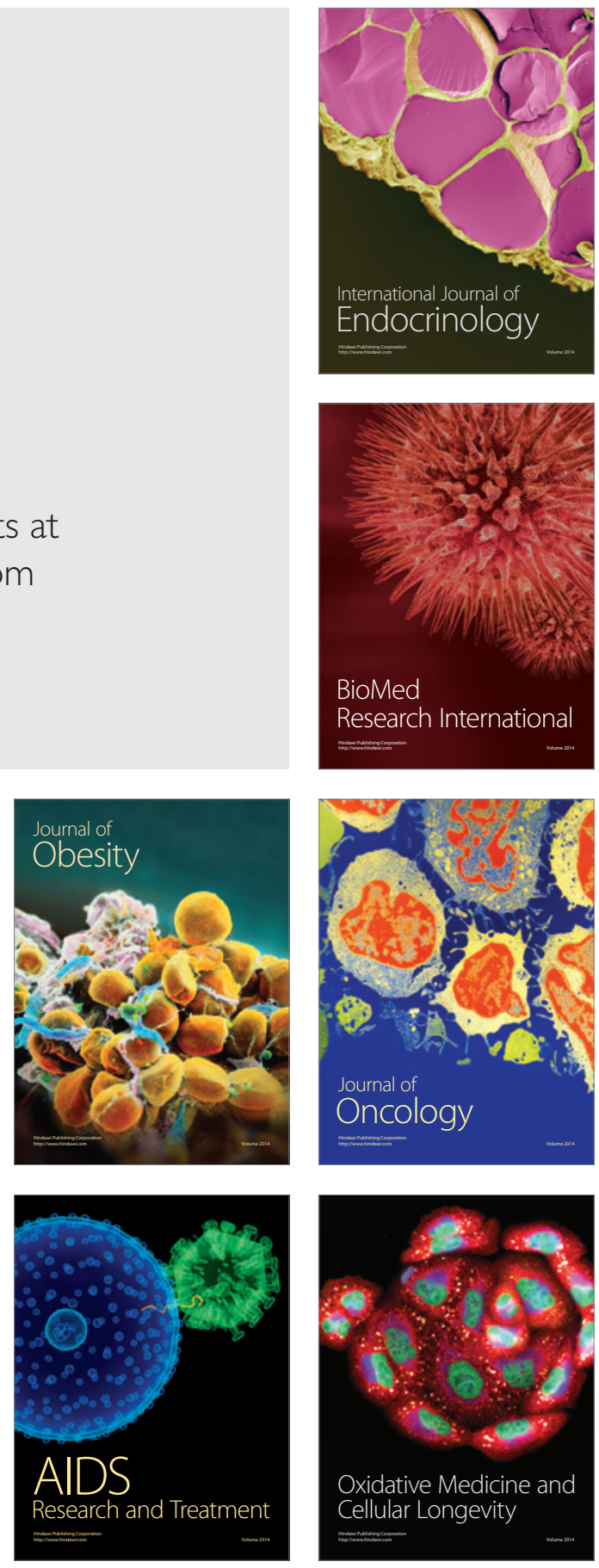